\title{
TEKS, VERWYSING, WAARHEID \\ Die relevansie van die verwysingskwessie vir die besinning oor die epistemologiese aard van die dogmatiek
}

C W DU TOIT

\begin{abstract}
TEXT, REFERENCE, TRUTH. The relevance of the reference issue to the reflection on the epistemological character of dogmatics.

In this article an outline is given of the way in which the reference of words, sentences and texts takes place. The emphasis is placed on the intra-textual text reference, which is also the meaning or world of the text. Some aspects of Derrida's notion of difference is considered and the différence-character of metaphor is recognized, especially in the diaphoric sense of the word. In the Christian faith, faith itself is a prerequisite for the ultimate reference of the religious text (which is to God). This makes the religious text autoreferential and intra-textual. Dogmatics is a science which is dependent on texts, and which continually transgresses and reinterprets these texts. This qualifies the truthcharacter of dogmatics as anti-metaphysical, metaphorical, relational and textual.
\end{abstract}

\section{Inleiding: Tekens en verwysing}

Die verwysingsvraagstuk is in ' $n$ groot mate die fokuspunt van resente nadenke binne die hermeneutiek, die literêre teorie en die teologie. Dit raak die meeste ander vrae aan wat in die nadenke oor teks, betekenis en waarheid na vore sou kon kom. Verskeie sake kom rondom die verwysingskwessie aan die orde: hoe verwysing binne tekstuele verband plaasvind, hoe tekste na mekaar verwys, hoe verwysing vanaf betekenaar na betekenis geskied, die wyse waarop tekste na mekaar verwys, die verwysing van die binnetekstuele na die buitetekstuele werklikheid, die wyse waarop stylfigure soos die metafoor verwys, die verhouding tussen verwysing en waarheid, ensovoorts. Omdat die verwysingskwessie relasionaliteit en ook relatiwiteit aan die orde stel, hou dit implikasies van epistemologiese aard in vir 'n wetenskap soos die dogmatiek wat met tekste werk. Die nadenke oor tekste en die manier waarop dit beteken, na waarheid verwys en waarheid teenwoordig stel, het vrae aan die orde kom stel wat nie deur die dogmatiek vermy kan word nie. As ons kennis wil neem van die wêreld van tekste, moet ons 
kyk na die grond van alle tekste, naamlik die sisteem van tekens.

Tekensisteme lê nie net ten grondslag van tekste nie, maar van die hele bestaan van die mens. Die teken is vir die mens ' $n$ leefmiddel." Ons leef in 'n wêreld vol tekens. Tekens verwys meestal as gelyk-aantekens na die een of ander saak of objek. Ons verwys na mense, gebeure, dinge of idees met tekens. Ons kommunikeer met tekens - taaltekens, liggaamlike tekens, simbole. Ons word gebore in 'n gevestigde tekensisteem, leer dit hanteer, leef daarin en dra by tot die groei en verandering daarvan. Hoe ons ook al teenoor hierdie tekens voel, ons kan ons nie daarvan losmaak nie. Al reageer 'n skrywer teen die taal, styl, gewoontes en tekens van sy tyd, doen hy dit nie in 'n lugleegte nie, maar in dieselfde taal en met die bronne van sy tyd. ${ }^{2)}$ Tekens kan baie komplekse sisteme wees. Nie alle tekens verwys eenvoudig net na een saak nie. ' $n$ Teken kan ook baie betekenisse hê. Normaalweg is tekens so ' $n$ vanselfsprekende deel van ons lewe dat ons hulle onbewustelik gebruik. Baie tekens op sosiale, godsdienstige en liggaamlike vlak is elke dag ongeartikuleerd en onbewus aan die werk. Woorde is ook tekens en werk soos gebruiksartikels. ' $n$ Gebruiksartikel is nooit ' $n$ doel op sigself nie maar staan in diens van iets anders; so ook die teken. Daar kom wel tye dat 'n mens bewus is van die instrument- of tekenkarakter van die teken, maar dit is die uitsondering. Gewoonlik is ons onbewus van die teken self.

Ten spyte van verskillende en komplekse tekensisteme, en al verwys tekens nie vir almal op presies dieselfde manier nie, lyk dit tog of die samelewing oor die algemeen goed funksioneer met sy tekensisteme. As ' $n$ teken ' $n$ betekenisverskuiwing ondergaan of uitgediend geraak het en nie meer beteken wat dit gewoonlik beteken nie, kan dit daartoe lei dat die teken verwerp word en 'n nuwe een geskep word. So is die tekensisteme in enige samelewing voortdurend aan die beweeg en verander.

Tekens as woorde word "geberg" in woordeboeke, maar word in die lewende gesprek elke keer op 'n unieke wyse met mekaar verbind om betekenis te gee. Soos ons deur die willekeurige verbinding van woorde tot ' $n$ oneindige aantal sinne kan kom, kan ons uit die verbinding van sinne tot ' $n$ oneindige aantal tekste kom, en so kan ons ook 'n oneindige aantal tekste met mekaar verbind in enige spesifieke navorsing of studie. So bestaan daar nie maar enkele woorde, sinne of tekste wat as 'n onbeweeglike norm altydgeldend is nie. Wie in taal, dus in tekens as woorde, sinne en tekste leef, is altyd binne die sisteme aan die beweeg.

As die mens in taal leef, leef hy in en deur tekens en veral van die interpretasie van hierdie tekens. So kon Derrida sê dat daar niks buite interpretasie bestaan nie. Alles is interpretasie. ${ }^{3)}$ In 'n samelewing ontstaan daar ook ' $n$ interpretasie-tradisie met sterk normgewende gesag. ' $n$ Bepaalde tekstradisie kan so omvangryk en gevestig raak dat dit skyn- 
baar as ' $n$ wêreld op sy eie sonder die "wêrelde" buite die tradisie kan klaarkom. Die ontwikkeling van 'n tekskultuur met 'n tekstuele (dus literêre) tradisie het geleidelik gelei tot 'n eie wêreld van tekste en outeurs. Dit is 'n wêreld waarin daar mettertyd eie reëls, norme en verwysingsisteme ontstaan het, 'n wêreld waarin tekste op tekste bou, waarin tekste oorgeskryf, gekommentateer, geappendeer, en geamputeer word.

In dié wêreld gaan dit nie meer om die "buitewêreld" waarmee die binnewêreld van die teks, of die wêreld van metatekste, ooreen hoef te stem nie. Alles gaan dan om die intra-referensiële wêreld van die teks en tekste self. Die wêreld het genoeg "middele" om selfstandig te bestaan. Is meer as 90 persent van alle boeke nie maar boeke oor ander boeke nie? Die wêreld van die godsdiens is ook 'n wêreld van tekste, en om die godsdienstige en teologiese ontwikkeling in die Weste te verstaan, moet die ewolusie in die wêreld van tekste in ag geneem word.

\section{Die verhouding tussen die tekstuele binne- en buitewêreld}

\subsection{Die verwysing van die woord, sin en teks}

Tekstuele verwysing handel oor die interaksies tussen linguïstiese elemente (verwysing tussen woorde en sinne), strukturele elemente (die strukturele balans en verhouding binne die teks), literêre elemente (verwysing tussen tekste, stylvergelykings), die verwysing tussen die binnetekstuele en buitetekstuele elemente, en so meer. Nie alle woorde verwys nie. Normaalweg verwys naamwoorde, soortname en byvoeglike naamwoorde (byvoeglike naamwoorde wat attribute aandui, sou in isolasie beskou wel betekenis hê, maar geen referent nie). Woorde, sinne en tekste verwys as tekens na mekaar. Soos 'n woord sy betekenis verkry vanuit sy verhouding tot ander woorde, so verkry die sin en die teks in breër verband hul betekenis in verhouding tot ander sinne en tekste.

Aan De Saussure het ons die produktiewe, dog problematiese onderskeidinge tussen sinkronie - diakronie, langue - parole, betekenaar (signifiant) - konsepbetekenis (signifié) te danke. Die betekenaars vorm die uitdrukkingslaag in 'n teks en die betekenisse die inhoudslaag daarvan." De Saussure het beklemtoon dat daar in taal net verskille is sonder positiewe terme. Hiermee het hy "identiteit", die hoeksteen van enige metafisika, gerelativeer. De Saussure het ons daarop attent gemaak dat die betekenis van ' $n$ woord nie soseer die woordreferent is nie, maar die akoestiese beelde, die mentale inhoud waarmee die woord geassosieer word. Die klem val dus op die "bin- 
newêreld" van betekenis en nie op die "buitewêreld" waar die dinge fisies gesien word nie. Met dié onderskeiding het hy die eeue-oue verbinding tussen denke (intellectus) en saak (res) buite die denke opgehef. Die onderskeid signifiant - signifié (betekenaar - betekenis) bly beperk binne die teken self. Die idee dat woorde denotatief (spesifiek aanwysbaar) refereer na die buitewêreld, lê ook ten grondslag van die idee dat woorde 'n "basiese" betekenis het." Alhoewel die enkele woord "perd" ook na 'n werklike buite-linguistiese entiteit kan verwys, gaan die verwysing in die sin of predikaat om die mentale betekenis wat die $\sin$ of stelling wil oordra. Die woord in dié sin het dus 'n spesifieke sinimmanente doelwit. ' $n$ Sin hoef nie na die aanwysbare werklikheid te verwys nie en kan 'n van-die-werklikheid-onafhanklike uitspraak maak.

Hierdie onderskeiding geld analogies in bepaalde opsigte ook vir die sin en die teks as geheel. Woorde as tekens verwys dikwels dubbelsinnig of ekwivokaal. Die ekwivokale woord bank (sitbank, geldbank, klipbank, ens.) kry in die filtreringsproses van die sin betekenis.

Die woord, sin en teks as teken wil, soos die oog onbewus van sigself is, ook onbewus van die letterlike betekenis wees, en wil as instrument fokus op die betekenis waaroor dit gaan. Die teks verwys dus met al sy komponente na die saak wat die teks in die midde lê. So is die saak of betekenis van die teks 'n binnetekstuele aangeleentheid. Die wil tot 'n univokale verbinding tussen teks en werklikheid het sy metafisiese oorsprong in die adequatio intellectus et res-gedagte. Soos betekenis die ooreenstemming tussen die reële ding buite my en my denke is, so is die teksbetekenis die ooreenkoms tussen die teks en die buitetekstuele realiteit. Die begrip "werklikheid" en "self" is albei egter problematiese begrippe, en het in die moderne tyd ook betekenisveranderinge ondergaan. Die werklikheid is ten laaste 'n baie subjektiewe begrip en die "self" as setel van alle selfbewussyn en beoordeling is ook nie ' $n$ betroubare en vasstaande verwysingspunt nie. ${ }^{6)}$

Die teks het uiteraard ook implikasies vir die buitetekstuele werklikheid. Die tekstuele buitewêreld raak spesifiek die interaksies wat daar tussen die teks en die leser, die teks en ander tekste, die teks en die tradisie, die teks en die lesersgemeenskap, ensovoorts, ontstaan, eerder as wat dit om die denotatief-aanwysbare buitewerklikheid gaan. Die probleem met die interpretasie van tekste kom gewoonlik na vore wanneer gevra word na die buitetekstuele verband, na dit wat die teks vir die huidige omstandighede te sê het, watter etiese of normatiewe riglyne dit vir die leser se spesifieke situasie bied. Hier is die omstandighede dikwels die oorwegende faktor en nie die teks nie. Soos die woordbetekenisse uit die sinsverband gefiltreer word, so word die teksbetekenis uit die buitetekstuele lewensverband gefiltreer. Om die legitimiteit van sulke 
afleidinge te beoordeel, moet gekyk word na die spesifieke tipe literatuur wat ter sprake is en of die teks sigself leen tot sulke afleidings. Daar moet onderskei word tussen die wêreld wat die werk voor die leser open in die teksgerigte omgang met die teks, en die wêreld wat die leser uit die teks uit dwing met die oog op bepaalde magstrategieë. Alle tekste, in soverre as wat hulle betekenis dra, kan sekerlik met die leser se eie wêreld in verband gebring word. Dit is egter moeilik om dit wat die een leser as teksbetekenis aflei, normatief te maak vir alle ander mense. Sodanige afleidings word normaalweg ook net gemaak uit tekste wat aanspraak maak op normatiewe gesag, soos wetenskaplike of religieuse tekste. Dit is egter juis dié tekste wat dikwels gebuk gaan onder ideologiese slawerny. Ook teologiese tekste kan hieraan skuldig wees as tekste net met die oog op iets anders, soos teorie- of dogmavorming, gebruik word. Die teks kom min in die proses van dogmavorming binne konteks tot sy reg. Die probleem is dat by sodanige afleidings die konteks van die teks oorskry word, en dat abstrakte en kontekslose norme redelik verskillend en selfs teenstellend verkonkretiseer kan word. Wanneer 'n Bybelse begrip soos liefde of regverdigheid verkonkretiseer word, verskil mense oor die wyse waarop dit geskied. Dit is omdat by enige abstraksie die woord sy verwysing na 'n indiwiduele objek verloor en 'n algemene betekenis kry."

Daar is wel ook geskrifte wat hulle betekenis vind slegs in die letterlike verwysing na die buitewêreld. Die vraag is net in watter mate sodanige geskrifte nog as tekste beskou kan word. Vergelyk so die kookboek, die telefoongids of die teks wat 'n aantal moralistiese voorskrifte bevat. Die tekste kan almal as gidse beskou word wat niks meer sê as die inligting wat dit gee nie. Dit is eenduidige tekste wat die leser as subjek geheel uitskakel, die leser verobjektiveer en sy handeling voorskriftelik bepaal. As daar van die letterlikheid van die teks afgewyk word, dan misluk die doel van sowel teks as leser. Die teks laat geen ruimte vir iets soos ' $n$ horisonversmelting nie, aangesien die horison van die leser ontken word. Dit raak veral die moralisties-voorskriftelike dele in 'n religieuse teks wat nie 'n wêreld open soos die tekste waardeur sonde opgeroep en beleef en bely word nie. ${ }^{\text {') }}$

\subsection{Die nulgraad van die skrywe}

Fiktiewe taal, waar dit nie primêr gaan om verwysing na die werklikheid nie, is nie ' $n$ ander soort taal as taal wat wel na die werklikheid verwys nie. Daarom is daar nie noodwendig ' $n$ verskil tussen taal wat na buite verwys en taal wat nie so verwys nie. Die teks kan dus vry wees van alle buitevrae, vry van subjektiewe beoordeling, vry van alle pogings tot 
psigologiese interpretasie, vry van historiese en redaksionele ontwikkeling. Ons kan met die suiwer teks werk, die teks as struktuur en verhouding. Tog is die teks meer as dit, want die struktuur en inhoud van die teks waarborg nog nie die spreke van die teks, dit wil sê sy wêreld nie.

'n Teks handel nie net altyd oor iets nie - dit is self daardie iets. Die teks handel dan as teken oor dit wat in die teks beteken word en aan die orde kom. Dit is die idee van die nulgraad van verwysing wat ontstaan het by die Deen Bröndal. Hy sien die nulgraad as die neutrale taalteken wat nie na buite verwys nie, maar onmiddellik sy verwysing in sigself het. So val binne en buite, woorde, dinge en mense direk saam. ${ }^{9}$

Ricoeur het met die probleem gesit dat die poëtiese teks meestal glad nie "verwys" nie. Die gedig wil nie verwys nie, dit stel iets teenwoordig. Dit waarna die gedig wil verwys, is die gedig self. Die werk is dus selfverwysend van aard. Dieselfde idee vind ons by Roland Barthes. $H y$ bepleit ' $n$ taal wat nie gebuk gaan onder die verpligting van voortdurende verwysing of verteenwoordiging nie. Die klem val vir hom op 'n intransitiewe skryfstyl. Wie skryf, wil nie spesifiek altyd kommunikeer nie, maar wil in en deur taal skep en uitdruk. Daarom val die klem op die vrye spel van taaltekens sonder die dwangbuis van verwysing.

\subsection{Post-strukturalisme: verwysing en "différence"}

Dit is Derrida wat as post-strukturalis binne dekonstruktiewe raamwerk die gebruik van die term différence (verskil, verwys of verplaas) ingelui het. Derrida as post-strukturalis sien die hermeneutiek as die proses waardeur die dubbelsinnigheid in tekste en kultuurprodukte ontdek word, en waardeur hierdie dubbelsinnigheid die moontlikheid open vir nuwe denke en dade. ${ }^{10}$ ) Die post-strukturalisme is ' $n$ benadering wat die konvensies en metodes wat verantwoordelik is vir die betekenis van die teks, aantoon, maar tegelykertyd ook beklemtoon dat dieselfde konvensies en kodes juis die teks oorskry en ondermyn (dekonstrueer). ${ }^{11}$

Différence beteken om te verskil en te verwys. Die oomblik dat iets verwys ('n teken verwys na iets anders), tree daar ook verskil in tussen die voorhande teken/betekenis en ' $n$ ander teken/betekenis. Die oomblik wat ek van 'n nuwe teken of saak bewus word, is die oomblik van identiteitsverlies en nuwe identiteit, die oomblik van différence. So is différence tegelyk identiteit en nie-identiteit. Die ooreenkoms met die metafoor lê voor die hand. Die metafoor identifiseer God epifories met 'n rots, terwyl dit diafories identiteit tussen God en 'n rots uitskakel. Die différence-karakter van die teken, en die meerduidige en diaforiese aard van die metafoor, sal nie binne die identiteitslogika aanvaarbaar wees nie. Derrida sien die teken as 'n spoor (voie). Hy sien taal wesenlik as 
spoor, en so as voortdurende verwysing.

Dit is nie net tekens as woorde en sinne wat na mekaar verwys deur van mekaar te verskil nie, dit is ook tekste wat as tekens so funksioneer. ' $n$ Hele teks kan as teken funksioneer en verwys na en verskil van ander tekste. Ons kenniskorpus bestaan eintlik uit ' $n$ interrelasie van gedifferensieerde betekenaars wat in tekste neergeskryf is en wat Derrida as een groot teks sien. Die netwerk en interafhanklikheid van tekste noem hy interteks. ${ }^{12}$ )

Om te skryf is vir Derrida ' $n$ indirekte en interpretatiewe reaksie op die wêreld. Wie skryf, interpreteer. Feitlik geen verwysing vind plaas sonder interpretasie nie. Dit gaan dikwels meer om die interpretasie van interpretasies as om die interpretasie van dinge. Die geskrif as betekenaar kan maar net altyd weer verwys na ander betekenaars. ${ }^{13)}$ Daarom beweer Derrida dat die analise van die teks of van die skryfakte ' $n$ analise is van ' $n$ pluridimensionele en diakroniese reeks betekenaars. Elke stukkie skryfwerk is maar ' $n$ aanvulling by ' $n$ ander stukkie skryfwerk. Daar is nie ' $n$ stabiele betekenissentrum wat aan ' $n$ uitdrukking 'n vaste en ewigdurende betekenis toeken nie. So is die teks of geskrif 'n metafoor vir alle menslike aktiwiteite wat plaasvind as ' $n$ ketting van gedifferensieerde verwysings. ${ }^{14)}$ Daar is geen oorspronklike aktiwiteit of betekenaar wat ' $n$ vaste, ewige verwysingspunt is nie.

Dit is die soeke na die "oorspronklike" betekenis van ' $n$ woord en selfs van ' $n$ sin of werk wat ons alte maklik in fundamentalisme laat beland, terwyl die klem op die relasionele en die sinkroniese nader aan die "waarheid" is deur juis die "waarheid" "weg te skuif". 'n Teken as woord of teks wat selfgenoegsaam is en sy waarde in homself het sonder verwysing na ander tekens, noem Derrida ' $n$ transendentale betekenaar. Dit hoort egter tuis in die metafisika waar 'n selfgenoegsame waarheid sonder enige ander konteks in ag geneem kan word. Die terugval op 'n gegewene wat "is" en altyd probleemvry is, noem Derrida ' $n$ "teenwoordigheidsmetafisika". Om hierteen te reageer is om te reageer teen die sogenaamde onmiddellikheid van die signifié by die signifiant. (Dit is ook 'n punt van kritiek teen die rasionalisties-Cartesiaanse identiteit van die denkende ek met die wêreld daarbuite.) ${ }^{15}$ )

Hierdie interafhanklikheid tussen tekste en tekens impliseer dat die strakke De Saussureaanse onderskeid tussen sinkronie en diakronie ook nie stand hou nie. ${ }^{16)}$ Die idee van ' $n$ vaste betekenaar en betekenis, met ander woorde eenduidige betekenis, is volgens Derrida te danke aan 'n teologiese siening van die teken wat eie is ook aan die fenomenologie en die strukturalisme. $(\mathrm{Vgl}$ in dié verband die beklemtoning in die teologie van Barth van die ewigheid van God, soos geopenbaar in Christus en soos dit neerslag gevind het in die Skrif). ${ }^{17}$ 
Die religieuse teks maak daarop aanspraak dat dit met ' $n$ suiwer betekenaar en suiwer betekenis te doen het, ten minste in soverre as wat die Goddelike outeurskap en betekenisgewing ten grondslag van die teks lê. So ' $n$ betekenaar is van geen ander betekenaar afhanklik nie, dus ontologies onafhanklik en nie verder terugvoerbaar nie. Dit maak natuurlik so 'n betekenaar ook los van alle ander tekens, van die tekensisteem en dus van taal self.

\section{Die verwysing van die teks na die wêreld wat deur die teks geopen word}

Die konnotatief-denotatiewe onderskeiding as verdeling van die buitetekstuele en binnetekstuele werklikheid is bloot teoreties. Die ervaring van ' $n$ leeftyd en die kennis van ' $n$ hele wêreld is meestal 'n voorveronderstelling om net ' $n$ minuskule deeltjie van die werklikheid waarna ' $n$ teks verwys, te verstaan. Die teks veronderstel gewoon ook dít waarna dit nie verwys nie. Al word die buitewêreld veronderstel, net soos die leser se leeskennis veronderstel word, handel die werk nie oor'n ander wêreld of ' $n$ leser se leeskennis nie. ' $n$ Werk of teks kan nie in sinne en woorde opgebreek word en deur middel van gelyk-aantekens met stukkies wêreld vergelyk word nie. ${ }^{18)}$ Die wêreld van die teks is die ontmoetingsveld van horisonne.

Heidegger se Welt-Erde-onderskeiding ten opsigte van die kunswerk bly eksemplaries vir die verstaan van die werking van die teks. Hy onderskei die stof (Erde) van 'n teks of werk, synde alles wat objektief uit 'n werk afgelei kan word, vanaf struktuur tot inhoud. Hiernaas stel hy die wêreld (We/t) van die werk wat nie uit die werk gedwing kan word nie en wat na vore kom wanneer die teks of kunswerk die mens tref. Die wêreld wat die werk voor die leser, hoorder of toeskouer open, kan nie met inspanning verkry word nie, en word as die openbaring van die werk beleef, as die mens-aanbetreffende en daarom treffende werklikheid waaroor die mens nie meer onbetrokke kan praat nie. Oor Erde kan 'n mens hermeneuties en struktureel beskik, maar by Welt is daar 'n teenstand teen elke vorm van kontrole van buite af. Ricoeur onderskei ook in dié verband tussen die distansiëring van die werk en die toeëiening van die werk wat dialekties met mekaar verbind is. Hierdie spanningsvolle jukstaposisie lei tot die kreatiewe rekonstruering van die teks, wat in die teenwoordigheid van die teks geskied. ${ }^{29}$ )

Die wêreld van die teks is selfstandig en nie afhanklik van die buitewêreld om outentiek te spreek nie. As die buitewêreld in die teks neerslag vind, gebeur dit steeds op so 'n manier dat die teks die verwysingspunt vir die wêreld word en die wêreld nie die verwysingspunt vir die 
teks is nie. Die buitewêreld word immers nooit bloot in die teks herhaal nie, maar juis beskryf, geinterpreteer, geskep. As Aristoteles praat van die mimesis - nabootsing - van die werklikheid in die teks, dan is dit nie nabootsing in die letterlike sin van die woord nie. Mimesis is herbeskrywing van die werklikheid.

Ricoeur het daarop gewys dat selfs die historiese teks nie bloot eenduidig na die werklikheid verwys nie. Dit het dieselfde narratiewe struktuure as wat die fiktiewe verhaal het. ${ }^{20}$ ) Tot sover Ricoeur. Die werklikheid van die historiese teks is dus die teks en nie die feitelik kontroleerbare buitewerklikheid nie. Om geskiedenis te lees of te skryf is verder om die historiese verlede te interpreteer as meerduidige en temporele opeenvolgings van menslike interpretasies van menslike interpretasies. Dit is by uitstek die historiese teks wat op ander tekste en uitsprake, tekens en kodes terugval om te probeer om te rekonstrueer, en die rekonstruksie is maar net nog 'n skakel in die ketting van betekenisgewing. Dit bevestig die nomadiese aard, nie net van alle tekste nie, maar van die historiese teks in die besonder. Ook die dogmatiese teks kan in dié lig beskou word.

Die wêreld van die teks is outonoom. Die betekenisgewende krag van die werk lê in die teks, al word die werking van die teks deur die leser met sy bepaalde horison bepaal. Die teks verwys nie eenduidig nie. Ek lees dieselfde teks nooit twee maal op dieselfde manier nie, nie as onthou word dat die teks my interpretasie van die teks is nie, nie as die wese van die teks beskou word as die betekenisgewende gebeure wat nooit vasgevat kan word nie. Ons kan nie anders as om met steeds veranderende horisonne weer na tekste terug te keer nie. Dan soek ons dalk tevergeefs na ' $n$ herhaling van ' $n$ vorige tekservaring toe die teks getref het, of dalk kom die nuwe wel na vore. Dit is die realiteit van die werking van tekste wat as wêreld getipeer word.

\section{Die verwysing van die metafoor}

Die metafoor word vervolgens gebruik in ' $n$ breër verband as dié van blote stylfiguur. Ook die sin of ' $n$ hele teks kan as metafoor funksioneer. Wat met die metafoor bedoel word, staan nie daar nie, en wat daar letterlik staan, is nie wat bedoel word nie. Die metafoor is ' $n$ denkleidraad. Dit stimuleer die denke maar skryf nie noodwendig voor nie. Dit suggereer betekenis, maar spel dit nie uit soos ' $n$ vergelyking nie. Die krag van die metafoor lê in die botsing tussen die vergelykingsdimensie daarvan (die epifoor), en die nie-vergelykende aspek daarvan (die diafoor). Die metafoor verwys en verwys tegelyk ook nie. Dit sê dat iets is, en ontken dit tegelykertyd. Sou die een moment, die epiforiese, uitgesonder 
word, dan is dit nie meer ' $n$ metafoor nie, maar bloot ' $n$ eenduidige verwysing, woordvervanging of woordspel.

Die diaforiese "dit-is-nie"-gedeelte van die metafoor waar paradoks, vaagheid, dubbelsinnigheid en meerduidigheid voorop staan, kan vergelyk word met die Erde van die teks (die struktuurelemente, inhoud) waaruit die We/t (die aanspreke van die teks, die rekonstruksie van betekenis) gebore word in die openbaringsoomblik van kreatiewe herinterpretasie en rekontekstualisering van dit waaroor die metafoor spreek. Wanneer die metafoor "oopgaan", is dit die oomblik van die nulgraadverwysing, die teks wat gebeur, wat in die plesier van onmiddellikheid nie meer betekenis uitstel nie, maar betekenis vier. Dit is betekenisviering waar betekenis toegeëien word deur die eie verbeelding en deur die spontaan improviserende omgang met die metaforiese teks. In 'n mate is die oomblik van betekenisgebeure die oomblik waarin 'n faset van die werklikheid deursigtig word. Die oomblik wanneer dit deursigtig word, word dit ook vernietig. Vergelyk die grap wat nooit weer so geniet word soos die oomblik toe dit die eerste keer gehoor is nie. So is dit ook met elke faset van dié van die metaforiese verwysing wat iets deursigtig maak. Die toekoms van die egte metafoor lê juis in die vermoë daarvan om weer betekenis te verberg agter die "is-nie"-element, die différence-element van die metafoor. Elke betekenisverdigting lei tot 'n herrangskikking van die kaarte vir 'n volgende spel.

Die interaktiewe metafoorsiening, waar die twee helftes van die metafoor op mekaar inwerk, maak dit onmoontlik om die metafoor net as verkorte vergelyking, as taalversiering, woordvervanging of predikasie te sien. Die implikasie hiervan is dat daar nie uitgegaan kan word van vasstaande en onveranderlike woordbetekenisse nie, maar dat betekenis geskied deur die inwerking van woorde en kontekste op mekaar. ${ }^{21)}$ Die metafoor is ' $n$ ongemaklike herinnering dat nie alle verskynsels ewe maklik met kodes vasgevat kan word nie. Metafories geskied dekodering en herkodering van betekenis oor die hele veld van menslike betekenisgewing heen.

Dle produktiwiteit van die metafoor vir die teologiese arbeid lê voor die hand en daar word ook al hoe meer vanuit verskeie oorde klem op die metafoor gelê. 'n Voorbeeld van die voorkoms en gebruik van die metafoor, van die diaforiese beklemtoninge van sake, die gebruik van jukstaposisie, ensovoorts, vind ons in die werk van Crossan. Hy het in 'n poging om die kernparabels van Jesus te rekonstrueer, aangedui dat die parabel ' $n$ inherente spanning bevat wat ook die krag daarvan is. Hy wys op die polêre ommekeer van verwagting, die gebruik van jukstaposisie en polivalensie in die kernparabels van Jesus, waardeur 'n meningsverandering by die hoorders teweeggebring word. Die parabel bewerk ' $n$ 
polêre ommekeer van verwagtinge en word metafories verwoord. Crossan kom self tot die ontwerp van 'n sogenaamde "negatiewe teologie" in lyn met Derridiaanse beklemtoninge, waar die afwesigheid van ' $\mathrm{n}$ betekenissentrum die spelelement beklemtoon. Dit kan nie los gesien word van die diaforiese model nie. ${ }^{22}$ )

Die klem op metaforiese openheid, meerduidigheid en kreatiwiteit vertoon sterk ooreenkomste met die dekonstruktiewe siening van die différence-karakter van taaltekens. Die metafoor wil nie fikseer nie - dit leef van relasionaliteit. Dit is aangewese op verbeelding of diaforiese spanning wat aanleiding gee tot voortdurende herinterpretasies van ' $n$ werklikheid wat nie finaal onder woorde te bring is nie.

\section{Die aard van waarheid in die teologie soos bepaal deur die aard van verwysing}

\subsection{Die rol van geloof in die verwysing van die godsdienstige teks}

Die grenskarakter van geloofstaal, sê Van Huyssteen, is die relasionele of verwysende aard daarvan. ${ }^{23}$ ) Maar hoe verwys geloofstaal en die godsdienstige teks? Ons verwys na God deur die geloof en in die taal van die geloof. So is geloof tegelyk die draer van en voorwaarde vir openbaring. Geloof word deur 'n teks gewek wanneer die teks 'n wêreld open wat die mens tref èn verander, ' $n$ ervaring wat as insigervaring, bekeringservaring of herskeppingservaring gedefinieer kan word. Die wyse waarop die religieuse teks ' $n$ wêreld open wat die leser tref, is dieselfde as dié van ander tekste, net soos die taal van 'n religieuse teks gelyk is aan die taal van ander tekste. Tog is daar ' $n$ verskil ten opsigte van die wyse waarop 'n religieuse teks tref. Die verskil tussen die religieuse teks en ander tekste vind ons in die wyse waarop die religieuse teks vir sy lesers verwys, asook die realiteitskarakter van die referent van die religieuse teks. Die verwagtinge wat van 'n godsdienstige teks gekoester word, bepaal in 'n groot mate ook die aanspreke daarvan. Dié teks lê vir sy lesers op 'n ander vlak as die sekulêre teks waar God nie aan die woord is nie.

Die referent van die godsdienstige teks - ten laaste altyd God - is vir die gelowige ook ' $n$ buitetekstuele realiteit, alhoewel Hy net binnetekstueel geopenbaar word en nie buitetekstueel aanwysbaar is nie. Die geloof wat die teks vir die leser "oopmaak", word beleef as geskonke geloof. Die wyse waarop geloof gewek word, is normaalweg deur medium van tekste: die lees, aanhoor en interpretasie van tekste. Die Bybelse teks maak ook self aanspraak daarop dat dit die geloof wek.

Die Bybelse teks verwys wel op baie plekke na die historiese agter- 
grond en ander feitelikhede wat gekontroleer kan word met behulp van ander tekste om die aansprake van die Bybelse teks te bevestig. Dit het egter nie ten laaste die historiese verwysings en feitelikhede as referent nie, maar die transendente Goddelike werklikheid wat deur geloof alleen geken kan word. Religieuse tekste wat op Goddelike openbaring en spreke aanspraak maak, is op 'n manier verwysinglose tekste omdat 'n Goddelike spreke, waarop die teks aanspraak maak, die kwessie van verwysing na ander tekste of ander waarhede oorbodig maak. Die godsdienstige teks is dus outo-referensieel omdat hy sy gesag en verwysing in homself besit. In soverre as wat die Bybelse teks op geloof appelleer om te sprrek, in dié mate is die teks outo-referensieel, want die geloof, wat 'n voorwaarde vir "ware" verwysing is, word deur die teks self opgewek. So geld dit ook die werking en toeëining van die grondmetafore soos Christus, ve, lossing, liefde en so meer, dat dit deurt die tekswerking self vir die leser werklikheid word. Wel is die tekste ingebed in die konteks van ' $n$ bepaalde religieuse gemeenskap waar die tekste via die prediking en die gemeentelike lewenstyl aan die orde kom, maar die bron vir die opwekking van geloof in die tekssaak bly die teks. Tog is dit die tradisie waarin die leser leef wat sy verwysingspunt is en wat in beslissende mate ook bepaal hoe die teks vir hom gaan verwys. ${ }^{24)}$

Godsdienstige waarheid is vir die gelowiges geloofswaarheid. Die waarheid van die religieuse teks lê daarom nie ontologies in die teks self, in sy struktuur of in die feitelikheid van die teks nie - dit kom deur die geloof wat die teks bewerk en dit so vir die gelowige leser tot ervaring maak. Sou die teks 'n bewys word vir 'n denotatiewe, buitetekstuele werklikheid, sou die voorvereiste van die geloof as geskonke toegang tot die geloofswerklikheid daarmee opgehef word. Dit gee aan die godsdienstige teks ' $n$ solipsistiese aard en stel dit in baie opsigte op dieselfde vlak as die poëtiese teks, waar die klem op die tekstuele binnewêreld val. Daarom behoef die geopenbaarde teks geen kontroleerbare buitewerklikheid nie. Daar sou 'n saak uitgemaak kon word vir die metafisiese siening van die godsdienstige teks, maar dit val buite die onderhawige tema.

Bogenoemde verklaar ook waarom die klem in die godsdiens op die woordgebeure (Ebeling) of die dinamiese inspirasieleer geplaas word (Barth) waar die teks as lewende gebeure 'n verandering in die mens bewerk. (Vgl. in dié verband ook Barth se analogia fidei waar die subjek self by die teksgebeure betrokke is en die tekstuele openbaring persoonlik toegeëien moet word.) Omdat Godsdienstige tekste gewoonlik na 'n tyd gevestig is en daar nie meer gevra word na die outentisiteit daarvan nie, skep die teks ook ' $n$ besondere verwagtingskader omdat die teks die potensie het om as geopenbaarde teks steeds weer gebeure te 
word.

Godsdienstige tekste verwys ook nie op 'n eenduidige wyse nie, en daar is ' $n$ veelheid van moontlike interpretasies en sieninge, waaroor daar ook verskil van mening kan bestaan. In die Christelike tradisie het die Skrif gefunksioneer as 'n tekenbron vir 'n oneindige aantal verwysings soos dit neerslag gevind het in die belydenisskrifte en teologiese werke. Die veelheid van hierdie werke bewys die onherleibaarheid van die Skrif tot enkele univokale betekenaars.

Die verwysing van die dogmatiese teks is dus primêr binnetekstueel van aard. Dit het ingrypende implikasies vir die waarheidsvraagstuk in die dogmatiek wat 'n verskuiwing ondergaan het vanaf 'n abstrakte metafisies georiënteerde uiteensetting daarvan tot 'n taalmatige en intertekstuele beklemtoning daarvan. Die weg is hermeneuties voorberei deur die beklemtoning van die aard van geloofstaal en die metaforiese aard van die spreke oor God.

\subsection{Verwysing en die dogmatiek}

Die verwysingskarakter van taal raak die dogmatiek fundamenteel. Nie alleen funksioneer die dogmatiek by uitstek deur te verwys na tekste nie, maar die tekste waarna daar verwys word is self weer verwysings van en na ander verwysings. Die dogmatiek kan sigself nie distansieer van die bevindinge van ander wetenskappe wat ook met tekste werk nie. Die tekenkarakter van die teks, interafhanklikheid van tekste van mekaar, relasionaliteit en relatiwiteit van uitsprake sal onder oë geneem moet word. Binne hierdie skuiwende wêreld van verwysings het die dogmatiek in die verlede probeer om lugfoto's te neem wat die terrein oorsigtelik en verkenbaar maak. Dit is wel altyd 'n "verruklike" gebeurtenis, maar is ook sterk selektief van aard. Barthes het daarop gewys dat by 'n panoramiese visie 'n mens normaalweg soek na die bekende bakens (tekens) om jouself te oriënteer. Jy soek na die tekens wat jy uit jou geheue opdiep en weet daar moet wees. Vanweë die hoogte is so 'n visie altyd eufories en tog ook intellektueel omdat die denke ondersoek, identifiseer, verdeel en verbind. So 'n ontsyfering is ook 'n inisiasie, 'n inwyding in die visie op die totaliteit. ${ }^{25}$ )

Die dogmatiek leef van tekstuele panoramas. Dit is eufories, oorsigtelik, intellektueel en relasioneel. Wat van onder as 'n tekstuele doolhof van tekste en teksverbindinge ervaar word, kan van bo deur die dogmatiese "supervisie" tot 'n volledige legkaart verbind word. Tog is dit duidelik dat so 'n panoramiese oorsig 'n kompaktering van die werklikheid is wat die meerduidige omvang daarvan nie tot sy reg laat kom nie. 
So min as wat ons op Bultmanniaanse wyse die mite kan afstroop om die suiwer betekenis oor te hou, so min kan ons die narratief, die teks as eenheid ignoreer en net die konseptuele, dogmatiese of metaforiese kern daaruit abstraheer ${ }^{26)}$ Die dogmatiek sal moet aanvaar dat sy verhaal ' $n$ vervolgverhaal is en dat alle episodes nie in een korpus of aflewering kan geskied nie.

Tog moet die dogmatiek oor die grense van die indiwiduele tekseenheid heen kom tot die skep van 'n nuwe teks. Die dogmatiese teks is 'n nuwe verhaal wat bou op baie ander verhale. Dit is ' $n$ nuutskepping, 'n herinterpretasie van ander tekste. As aan die teks soos dit daar staan (bv. ' $n$ teks soos die Bybel) niks verander moet word nie dan sou alle teologiese biblioteke ook maar verbrand word, want die geskrifte sou of net sê wat reeds in die Bybel staan, of dit sou in elk geval afwykings wees van wat daarin staan. ${ }^{27}$

Die différence-karakter van die dogmatiek kan nie ontken word nie. Die geskiedenis van die dogmatiek is in groot mate die geskiedenis van die interaksie van dogmatiese tekste met mekaar. Dit bepaal die openheid van die dogmatiek na vore, die metaforiese meerduidigheid, en die spelelement daarvan. Daarom is die ingeboude self-relativerende aard van die dogmatiek die waarborg vir die nederigheid asook vir die voortgaande spreke daarvan.

Die ontstaansgrond van die teks soos die van die taal bly die lewe self. Die teologiese wêreld van tekste word steeds gekomplementeer deur die lewende tradisie, kultus, ensovoorts. Die teologiese taal staan ook nie los van die godsdienstige ervaring van die totale werklikheid nie. (En die ervaring sluit God, wêreld en mens in.) Hierdie werklikheid is egter nie eenduidig verklaarbaar en beskryfbaar nie. Dit is juis paradoksaal, meerduidig, sondig en dikwels misterieus. Die religieuse teks wat juis hierdie werklikheid herbeskryf, behoort dus ook van 'n meerduidige, voortgaande en selfs paradoksale aard te wees. Dat die teks dus eenduidig na die buitetekstuele werklikheid moet verwys is nie die waarborg dat die teks daarom metafisies vasstaande en metafisies ewig sal wees nie. Selfs nie eens die Goddelike werklikheid kan so beskryf word nie. Die immanensie van die godsdienstige teks kan vergelyk word met die "immanensie" van die gelowige gebed. Alhoewel die gebed vir die gelowige met die werklikheid te doen het, gaan dit in die gebed om die gebedswerklikheid, om my werklikheid soos dit in die teks om die tekstuele werklikheid gaan. Die gebed kan neergeskryf of herhaal word, maar dit kan die gebedsgebeure, die "gebedsontmoeting" nie vervang nie. Analogies geld dit ook so van die eie wêreld wat die teks open. ${ }^{28)}$

Die onbetwisbaar tekstuele aard van die dogmatiek het implikasies nie alleen vir die intertekstuele aard daarvan nie, maar ook vir die 
voorlopigheid en nomadiese aard daarvan. Dit hoef nie as beperkend ervaar te word nie en kan juis nuwe ruimtes oopstel. Dit is hierdie metaforiese aard van die dogmatiek wat ook moontlikhede vir nuwe konsep-, teorie- en dogmavorming daarstel. ${ }^{29)}$ Dit open ook moontlikhede vir die trans-konfessionele en trans-kulturele bedrywigheid van die protestantse teologie. ${ }^{301}$

Dit sou tog eensydig wees om weer te wil terugvra na die kriteria vir teorievorming, asof daar tog op ' $n$ manier ooreenstemming bereik kan word oor die daarstel van laaste beginsels in dié verband. Die hele postBarthiaanse teologie het in 'n groot mate steriel rondom die vraag na verifikasieprosedures gewentel. ${ }^{31}$ ' In die soeke na verifikasie kan die Bybel nie gladweg as kriterium nadergeskuif word nie. Die Bybel, sê Kuitert, vervul sy funksie in die dogmatiek nie as kriterium nie, maar eerder as bron van die christelike Godskennis. Die kompleksiteit van die verstaansvraag verhinder so 'n vereenvoudigde "vaste-kriteriumbenadering".32)

Voorts kan die diaforiese aard van dogmatiese uitsprake as model dien wat ruimte laat vir die différence-karakter van die dogmatiekbedrywigheid. Dit beklemtoon die tekstuele aard van enige teologiese of geloofsuiting, waarbinne die metaforiese interaksie van werklikhede, die jukstaposisie van groothede en diaforiese dubbelvisie van sake, die spanning van die teks handhaaf en tog ook stimuleer tot subversie van dieselfde groothede in ' $n$ voortdurende herinterpretasie van dié betrokke werklikhede. Die tekstuele spel-element relativeer waarheid in die sin dat dit "vernietigend" gevier word in die oomblik van betekenisgewing. "Meaning must await being said or written in order to inhabit itself, and in order to become, by differing from itself, what it is: meaning." ${ }^{33}$ )

\section{NOTAS}

1. C W du Toit, Die metaforiese spreke oor God, ongepubliseerde proefskrif, Pretoria 1984, 43 e.v.

2. Aussi l'écriture est-elle une réalité ambigué: d'une part, elle naît incontestablement d'une confrontation de l'écrivain et de sa société; d'autre part, de cette finalité sociale, elle renvoie l'écrivain ... aux sources instrumentales de sa création...ll n'est pas donné á l'ecrivain de choisir son écriture dans une sort d'arsenal intemporel des formes littéraires. C'est sous la pression de l'Histoire et de la tradition, que s'établissent les écritures possibles d'une écrivain donné..." Roland Barthes, $L e$ degré zéro de l'écriture, Paris 1964, 18-19.

3. H S James, "Hermeneutics, play, deconstruction", Philosophy Today, (1980), 303.

4. Vergelyk R Barthes, Elements de semiologie, Paris 1963, 111.

5. D A Carson, Exegetical Fallacies, Michigan 1984, 65.

6. C W du Toit, a.W., 208-211. 
7. P Ricoeur, The rule of metaphor, London 1978, 107.

8. Du Toit, a.w., 234-238.

9. H Hillenaar, Roland Barthes, Assen 1982, 4.

10. R Lundin, A Thiselton, C Walhout, The responsibility of hermeneutics, Michigan 1985,35 .

11. J van Luxemburg, M Bal, W Weststeijn, Inleiding in de literatuur-wetenschap, Muiderberg 1984, $80 \mathrm{ev}$.

12. F Merrell, Deconstruction reframed, Indiana 1985, 1-2.

13. J Derrida, Writing and difference, London 1978, 278.

14. W Dean, "Deconstruction and process theology", Journal of Religion vol 64 (1984), 4.

15. R J Bernstein, Beyond objectivism and relativism, Oxford 1983, 16-20, 115-118.

16. E Berns, S ljsseling, P Moyaert, Denken in Parijs, Brussel 1979, 160.

17. W Dean, Journal of Religion vol 64 (1984), 13.

18) Die wêreld is ' $n$ teks an die teks ' $n$ wêreld. Vergelyk $U$ Eco, The name of the rose, London 1984, 278-9 vir ' $n$ voorbeeld van die 12de-eeuse siening van die wêreld as 'n boek.

19. Du Toit, a.w., 42-56. Sien ook Lundin et al., a.w., 49-50.

20. Du Toit, a.w., 57-63.

21. Du Toit, a.w., 92-3, 349-350.

22. Vergelyk J D Crossan, Cliffs of fall. Paradox and polyvalence in the parables of Jesus, New York 1980, 8-11, 51-65. Vergelyk ook J M Strijdom, Progressie in die Christologie van J D Crossan?, ongepubliseerde BD-verhandeling, Pretoria 1986.

23. Vergelyk $W$ van Huyssteen, Teologie as kritiese geloofsverantwoording, Pretoria 1986, 159.

24. Van Huyssteen, a.w., 157.

25. Vergelyk Roland Barthes, "The Eiffel toweer", in: R Barthes, Selected writings, (S Sontag (ed.), 245-6, 237-250.

26. D H Kelsey, The uses of scripture in recent theologv, Philadelphia 1975, 34-37. Vergelyk in die verband Kelsey se behandeling van Wright se metode.

27. Vergelyk U Eco, The name of the rose, London 1980, 399.

28. Vergelyk Du Toit, a.w., 153-267 vir die wyse waarop die totale werklikheid godsdienstig beleef en tekstueel geuit word.

29. Vergelyk ook Van Huyssteen, a.w., 163 ev.

30. Alhoewel Van Huyssteen se beklemtoning van Kuhn se paradigma-teorie 'n kwessie soos die inter-/trans-kulturele en -religieuse wearheid van die hand wys, soos Krüger beweer, erken Van Huyssteen tog iets van die trans-konfessionele dimensie van die sistematiese teologie wat wetenskaplik en ekumenies-teologies bevrydend inwerk. Vgl Van Huyssteen, a.w., 171. Krüger sal moet uitspel wat hy onder die "waarheid" van ' $n$ inter-/trans-kulturele en -religieuse waarheid bedoel. Vgl sy resensie-artikel, Theologia Evangelica vol 20 (1987), 64-69. 'n Benadering soos die wat Krüger voorstel, waar die meerduidige aard van die teologie trans-kulturele kontakpunte moontlik maak is wel te vinde in die sogenaamde "intratekstuele" teologie van George Lindbeck. Vergelyk G A Lindbeck, The nature of doctrine. Religion and Theology in a postliberal age, London 1984, 113-135.

31. Vgl H M Kuitert, "Waarheid en verificatie in de dogmatiek", in: G C Berkhouwer en A S van der Woude (reds), Wat is waarheid? Kampen 1973, 111-144.

32. H M Kuitert, a.w., 123.

33. J Derrida, a.w., 11. 